\title{
Preface to the 1968 Edition
}

Since the summer of $19^{6} 4$ I have been engaged in a study of the life and writings of Sayyid Jamāl ad-Dīn al-Afghānī," best known as an ideologist of pan-Islam and of Islamic reform. One product of this study has been a detailed biography of Afghāni, of which an almost complete draft now exists. Portions of this long biography have appeared in preliminary form as articles, which are listed in the bibliography and footnotes of the present book.

In the course of this study of Jamāl ad-Din it became clear that some of the numerous misconceptions current about him were due to a failure to refer to his Persian-language writings and to heavy reliance upon Arabic articles in his newspaper al-'Urwa al-Wuthq $\bar{a}$, which represent only one phase of his thought and activity. It seemed useful, therefore, in order to make available a more complete picture of Afghāni, to analyze some of his more neglected writings, particularly those written in Persian, and to translate some of the most illustrative of them. In analyzing Afghäni's thought I have found it particularly important to indicate his relationship to unorthodox traditions of Islamic rationalist philosophy. A very brief version of Afghān's biography makes up the first chapter of this book, as background to the analysis of his thought.

The study of Jamāl ad-Din al-Afghanni's life and activities also necessitated reference to the Persian original of his most famous work, known in the West under the title of its Arabic translation, the "Refutation of the Materialists." It immediately became apparent that the Persian text was quite different from the Arabic text, which is a paraphrase rather than a translation. The Arabic translation was done by Muhammad 'Abduh, who knew no Persian but got

- Although, as the following pages show, Sayyid Jamāl ad-Din was born and brought up in Iran, not Afghanistan, I have continued to use the name "Afghăni" under which he is known everywhere outside Iran, rather than follow the technically accurate but unfamiliar Iranian practice of naming him after his native village of Asadabad. 
the sense of the original from Afghānī's Persian servant, Abū Turāb. Since the latter was not a learned man, the discrepancy between the original and the Arabic is not surprising. Until now the only Western translation of the "Refutation" has been from the Arabic, and hence shares 'Abduh's deviations from the original text. (This is Jamāl ad-Din al-Afghānī, La Réfutation des matérialistes, trans. A. M. Goichon [Paris, 1942], a volume that brings together much useful material.) Although the general sense of the Arabic text is similar to the Persian original, it seemed useful to provide an English translation of this widely cited work which was based on an accurate text. An idea of the difference between the Persian and Arabic texts may be obtained by taking almost any substantial section of the English translation herein and comparing it to Mlle. Goichon's French translation from the Arabic. In general, the Arabic is a somewhat longer paraphrase of what Afghāni is presumed to have meant. When his Persian text is ambiguous or obscure, as it frequently is, words or phrases are often added indicating what the translators thought Afghānī meant. Since there is no evidence that Afghānī approved or corrected the Arabic translation, it seemed better to try to avoid reliance on the paraphrases of the Arabic version when doing the present translation. I have not tried to duplicate Mlle. Goichon's most useful detailed annotations of the persons and schools referred to by Afghānī; those interested should refer to her work.

I did the original translation of the "Refutation" from a recent Tehran edition, but subsequently obtained from the Majlis Library in Tehran a microfilm of the original Indian lithographed edition. Hamid Algar of the Near Eastern Languages Department, University of California, Berkeley, did the difficult work of checking my entire translation against these rather illegible photographs and made various revisions, many of which were based on correcting errors in the more recent edition. Dr. Algar also checked, and suggested revisions for, the translation of "The Benefits of Philosophy."

For the translations of articles it was not possible to refer to first editions, but the editions used contained none of the obvious errors found in the Tehran text of the "Refutation." The Persian articles were translated from Maqālät-i jamäliyyeh (Tehran, $1312 \mathrm{~h}$. solar/ 1933); "The Materialists in India," from the Cairo, 1958, edition of al-'Urwa al-Wuthqā; and the "Answer to Renan," from Mlle. Goichon's translation of the "Refutation," referred to above.

Although Afghāni's writing is often obscure, particularly where, as in "The Benefits of Philosophy," he is discussing technical ques- 
tions of traditional Islamic philosophy, I have preferred not to burden the text or notes with a heavy scholarly apparatus or possible alternate meanings. On the points that I am most concerned to illustrate-Afghānī's political and religious views-there are no major ambiguities or obscurities in the texts. In general, the translations follow the pattern of being as literal as is consistent with smooth English usage. This has meant breaking up long sentences; providing clear antecedents for the ubiquitous $i t$ 's and he's of Arabic and Persian; but retaining much of the rhetoric and reiterations of synonomous phrases so characteristic of Afghānī's style.

Transliteration in a text that deals with Arabic, Persian, and Turkish words and works presents peculiar problems, for which every author will have his own solution. Mine has been to use the modern Turkish Romanization for Turkish; the standard system adopted by the UCLA Near Eastern Center for Arabic; and a modification of this Arabic system for Persian, whereby the vowels are transliterated in the Arabic system, while consonants are given their Persian pronunciation without the diacritical marks that distinguish between different letters pronounced in the same way. In the notes and bibliography, however, I have added standard diacriticals to the Persian consonants as an aid to anyone who might wish to look up an author or work in Persian. Place-names and words whose position in English is attested by their inclusion in recent unabridged dictionaries are presented without diacriticals, although the sign for 'ain is retained in the middle of such words: as ulama, Shi'i, Isma'ili, Babi, Muhammad. Neicheri is spelled in a way that has become common in English.

My work on Afghānī has been almost a group project, so much have I called on the generous help of others. For the material included in this book I would like to record heartfelt thanks to Mrs. Homa Pakdaman of Paris, who has shown me her thesis on Afghāni, which includes numerous important and excellent translations. I want to thank her particularly for allowing me to refer to her translations of the "Lecture on Teaching and Learning," and "Commentary on the Commentator." My translations were done directly from the Persian, but reference to her translations sometimes helped clarify dubious points. Also deserving profound thanks is Elie Kedourie of the London School of Economics, who first suggested I undertake a biography of Afghāni and has made numerous useful suggestions, not only regarding the completed text, but at all stages of my work. Although our views on Afghānĩ are not at all identical, Professor 
Kedourie has been unstintingly generous in forwarding my study. My colleagues Amin Banani and Moshe Perlmann have also given most generously of their time and knowledge in answering numerous questions about translations from Persian and Arabic. Professor G. E. von Grunebaum, director of the Near East Center at UCLA, has also encouraged my work from the beginning, and has read the entire work and made useful suggestions for changes. The work, in an earlier stage, was also generously read and commented on by Hamid Algar and Ira Lapidus of the University of California, Berkeley, and by Benjamin Schwartz of Harvard, Aziz Ahmad of the University of Toronto, and Muhsin Mahdi of the University of Chicago. Errors and deficiencies that remain are, of course, mine alone. Useful suggestions have also come from conversations and correspondence with Professors H. A. R. Gibb; Bernard Lewis of London; Albert Hourani of Oxford; Niyazi Berkes of McGill, Montreal; Joseph R. Levenson and William Brinner of the University of California, Berkeley; Maxime Rodinson of Paris; and Iraj Afshār, Asghar Mahdavī, 'Abd al-Husain Zarrinkūb, Sayyid Hasan Taqīzādeh, Muhīt Tabātabā'ì, Mojtaba Minovi, and Sifātallāh Jamālì (Afghānī's grandnephew) in Tehran. Dr. Zarrinkūb, in particular, gave freely of his time and help when I was in Iran and suggested a number of ideas about Afghāni and his Persian followers which are fundamental to the present work. Those whose help contributed mainly to the longer biography include my colleagues Andreas Tietze and Janos Eckmann and various acquaintances in Cairo and Istanbul, who will be thanked more adequately in that work. My research assistants, Miss Shannon Stack and Mr. Gene Garthwaite, and my editor, Kathleen Jasonides, have also helped above and beyond their duties.

The study was helped financially by grants from the John Simon Guggenheim Foundation, 1963-1964; the American Philosophical Society, summer, 1965; and the University of California Humanities Foundation, summer, 1966; to all of whom thanks are due.

I should like to conclude this preface in a heterodox way, by appealing to my readers for comments, criticisms, and corrections. Since my longer biography of Afghānī remains to be concluded and published, it should be possible to incorporate corrections and suggestions into that work.

N. R. K. 